\title{
HUBUNGAN PENGUASAAN KOSAKATA SISWA DENGAN KEMAMPUAN BERBICARA SISWA KELAS XI SMA NEGERI 1 LEDO TAHUN AJARAN 2016/2017
}

\author{
Oxtapianus Tawarik ${ }^{1}$ \\ ${ }^{1}$ SMA Negeri I Ledo, Bengkayang-Indonesia \\ Email: oxtapianus10@gmail.com
}

(Received: 16 Februari 2021; Reviewed: 7 Agustus 2021; Accepted: 23 Agustus 2021; Available online: September-2021; Published: September-2021)

(c) This is an open access article distributed under the Creative Commons
Attribution License
Attribution 4.0 International (CC BY 4.0) (https://creativecommons.org/licenses/by/4.0/ )

\begin{abstract}
ARTIKEL INFO
Kata Kunci:

Penguasaan

Kosakata Siswa;

Keterampilan

Berbicara; Studi

Korelasi.
\end{abstract}

\begin{abstract}
Abstrak. Penelitian ini bertujuan untuk mengetahui hubungan penguasaan kosakata siswa dengan keterampilan berbicara mereka. Penelitian ini dilakukan melalui desain korelasional. Sampel penelitian ini adalah siswa kelas XI SMAN 1 Ledo tahun pelajaran 2016-2017. Penelitian ini merupakan penelitian korelasi dengan Teknik pengumpulan data kuantitatif deskriptif statistic dan inferensial statistik. alat yang digunakan dalam penelitian ini adalah rubrik score speaking performance untuk mengukur keterampilan berbicara siswa, sedangkan untuk mengukur penguasaan kosakata siswa (vocabulary mastery) menggunakan Multiple choice test (tes pilihan ganda) dimana secara manual (test Item validity and reliability) telah dilakukan validitas dan relibilitas terhadap kedua alat test tersebut. Untuk menganalisis data didalam penelitian ini penulis menggunakan descriptive statistic (nilai individu atau individual score, nilai rata rata atau mean score) dan inferential statistic (pearson product momen correlation) untuk menghitung variable penguasaan kosakata (vocabulary mastery) dan keterampilan berbicara (speaking skill). Hasil penelitian ini menunjukkan bahwa untuk tingkat Kosa Kata dan Prestasi Berbicara Siswa pada kelas XI SMAN 1 Ledo berada pada tingkat yang baik. Peneliti juga menemukan bahwa terdapat korelasi positif antara penguasaan kosakata dengan keterampilan berbicara siswa kelas XI SMAN 1 Ledo tahun pelajaran 20162017 dengan signifikansi korelasi sebesar 0,943. Korelasi tersebut tergolong korelasi erat artinya kedua variabel memiliki korelasi yang kuat. Berdasarkan hasil penelitian dapat disimpulkan penguasaan kosakata dan keterampilan berbicara siswa berkorelasi positif, artinya tingkat penguasaan kosakata tertinggi maka tingkat keterampilan berbicara juga tinggi. Oleh karena itu, guru yang berperan dalam mengontrol siswa dalam proses belajar mengajar juga penting untuk mengetahui peningkatan kosa kata dan keterampilan berbicara.
\end{abstract}

Abstract. This research was aimed to find out the correlation between students' vocabulary mastery and their speaking skill. This research was conducted through correlational design. The sample of this research was the eleventh grade of SMAN 1 Ledo in the academic year of 2016-2017. This research is correlational research with techniques of data collection 
quantitative approach descriptive statistics and inferential statistics. The tools used in this research is the rubric speaking performance score to measure students' speaking skills and vocabulary mastery to measure student's vocabulary mastery skill. Both tools 'rubric performance and multiple-choice test' have counted for validity and reliability test. To analyze the data in this study, the writer used descriptive statistics (individual score and mean score) and inferential statistics (Pearson product-moment correlation). The result of this research showed that for the Students' Vocabulary and Speaking Achievement level were in good level at the eleventh grade of SMAN 1 Ledo. The researcher also found that there is positive correlation between vocabulary mastery and their speaking skill at the eleventh grade of SMAN 1 Ledo in the Academic year of 20162017 with the significance of correlation was 0.943. The correlation was categorized as close correlation it means both variables has strong correlation. Based on the research findings it can be concluded students' vocabulary mastery and speaking skill has a positive correlation it means that the highest level of vocabulary mastery the level of speaking skill also high. Therefore, the teachers who have roles in controlling the students in learning and teaching process are also important to know the improvement of the vocabulary and speaking skill.

\section{PENDAHULUAN}

Pemerintah Indonesia khususnya di bidang Pendidikan telah menjadikan mata pelajaran bahasa Inggris sebagai salah satu mata pelajaran wajib yang harus diajarkan siswa di sekolah di Indonesia mulai dari sekolah dasar hingga sekolah menengah atas. Seperti yang dinyatakan oleh Floris (2013: 30), "Departemen Pendidikan Nasional Indonesia telah mengizinkan sekolah untuk menjadikan bahasa Inggris sebagai mata pelajaran wajib mulai dari kelas satu sekolah dasar." Artinya Indonesia telah menempatkan bahasa Inggris sebagai salah satu mata pelajaran wajib yang harus dipelajari oleh siswa. Dalam pembelajaran bahasa asing terdapat empat jenis keterampilan yang harus dikuasai siswa, keempat keterampilan tersebut adalah: menyimak, berbicara, menulis dan membaca.
Keterampilan mendengar dan membaca bersifat reseptif, sedangkan keterampilan berbicara dan menulis produktif.

Salah satu ketrampilan produktif adalah berbicara yang memiliki peran yang sangat penting untuk dimainkan, terutama untuk memperoleh informasi dari penutur yang sedang berbicara, dapat memahami apa yang mereka maksud dari perkataannya. Jadi, sebagai pembelajar siswa harus dapat mengambil informasi dari penuturnya dengan jelas, efektif, dan dapat diterima. Seperti yang dikemukakan oleh Barras (2006: I), "Pembicara yang baik adalah pembicara yang dapat mengekspresikan dirinya dengan jelas, persuasif, berkontribusi secara efektif pada diskusi, mempersiapkan pembicaraan atau presentasi, menyiapkan alat bantu visual yang efektif, berprestasi dalam berbicara". Artinya siswa dituntut untuk menjadi 
pembicara yang baik yang mereka antara kosakata dan keterampilan butuhkan untuk mengekspresikan dirinya berbicara.

dengan jelas, efektif dan dapat diterima.

Peneliti dengan judul: Korelasi

Namun sayangnya keterampilan berbicara diabaikan keterampilan bahasa di banyak ruang kelas pernyataan ini sesuai dengan Baker \& Westrup (2003: 8), "Berbicara adalah keterampilan bahasa diabaikan di banyak kelas, siswa mungkin memiliki pengetahuan yang baik tentang tata bahasa dan kosa kata yang luas untuk mengekspresikan ide secara lisan bahkan siswa mampu tata bahasa yang benar, tetapi tidak pasti mereka telah diungkapkan secara lisan". Artinya tidak ada hubungan antara kosakata dan keterampilan berbicara.

Sedangkan ahli lainnya memiliki pendapat yang berbeda seperti yang dikemukakan oleh Loraine (2008: 1), "vocabulary is the basis for learning language". Penelitian pendidikan menunjukkan bahwa kosakata sangat terkait dengan pemahaman bacaan, kecerdasan, dan kemampuan umum". Pernyataan ini diperkuat oleh Nation in Alqahtani (2015), "Dalam bahasa Inggris sebagai bahasa kedua (ESL) dan bahasa Inggris sebagai bahasa asing (EFL), pembelajaran kosakata memainkan peran penting dalam semua keterampilan bahasa". Artinya penguasaan kosakata dapat memudahkan siswa dalam mengungkapkan ide atau perasaannya tentang sesuatu. Artinya sangat terkait
Penguasaan Kosakata dengan Speaking, Skill Anova et al (2013: 7) menemukan bahwa ada hubungan antara penguasaan kosakata dengan keterampilan berbicara yang dihitung dengan korelasi product moment dan hasilnya 0,559 . Ada korelasi sedang antara penguasaan kosakata siswa dan keterampilan berbicara mereka. Sari et al (2013: 12) dengan judul: Hubungan Antara Kemampuan Siswa Mendengarkan Lagu Bahasa Inggris dengan Penguasaan Kosakata mereka menemukan bahwa terdapat hubungan positif antara penguasaan kosakata dengan keterampilan berbicara yang telah dihitung dengan korelasi product moment dan hasilnya. 0,269 artinya tidak ada hubungan antara penguasaan kosakata dengan keterampilan menyimak. Yuwinda (2015: VI) dengan judul korelasi antara penguasaan kosakata dengan kemampuan berbicara pada siswa kelas XI Man Model Palangkaraya dihitung dengan korelasi product moment diperoleh hasil 0,948. Artinya terdapat korelasi yang sangat signifikan antara penguasaan kosakata siswa dengan kemampuan berbicara mereka.

Karena pernyataan dari beberapa ahli di atas maka peneliti melakukan penelitian, yakni apakah penguasaan kosakata dan keterampilan berbicara memiliki korelasi atau tidak dan seberapa 
signifikan itu? Semoga penelitian ini dapat bermanfaat bagi pembaca, peserta didik, guru dan peneliti lainnya.

\section{METODE}

\subsection{Desain penelitian}

Untuk mencapai tujuan utama penelitian ini perlu digunakan metode yang sesuai. Jenis penelitian yang digunakan adalah jenis penelitian korelasional. Creswell (2012: 126) menyatakan bahwa desain korelasional adalah prosedur dalam penelitian kuantitatif dimana peneliti mengukur derajat asosiasi (atau hubungan) antara dua variabel atau lebih dengan menggunakan prosedur statistik analisis korelasional.

$$
\text { Dalam desain penelitian }
$$

korelasional hubungan antar variabel dapat dijelaskan (Creswell, 2009: 233) disebutkan bahwa desain kuantitatif merupakan alat untuk menguji teori-teori objektif dengan cara menguji hubungan antar variabel. Variabel-variabel ini, pada gilirannya, dapat diukur, biasanya pada instrumen, sehingga data bernomor dapat dianalisis dengan menggunakan prosedur statistik. (Bernstein \& Bernstein 1999: 1) menyatakan bahwa dalam statistik deskriptif, teknik yang diberikan untuk mengolah data numerik mentah menjadi bentuk yang dapat digunakan. Berdasarkan pernyataan dari beberapa ahli di atas peneliti menerapkan desain korelasional.

\subsection{Populasi Penelitian dan} Pengambilan Sampel

Mengidentifikasi data sebagai sumber studinya sangat penting agar penelitian berjalan lancar ke jalur yang benar. Penting untuk mengetahui tentang populasi data. Populasi dalam penelitian ini adalah representasi dari seluruh populasi SMAN 1 Ledo. Seperti yang dikemukakan oleh Creswell (2012: 142) menyatakan "populasi adalah sekelompok individu yang memiliki karakteristik yang sama" artinya populasi adalah sekumpulan kelompok yang terdiri dari individuindividu yang memiliki karakteristik yang sama dimana peneliti akan melakukan penelitian didalamnya".

Hal ini juga diperkuat oleh Urdan (2005: 1), "Populasi adalah individu atau kelompok yang mewakili semua anggota kelompok atau kategori kepentingan tertentu". Artinya, populasi adalah semua anggota kelompok tertentu yang dikategorikan tertarik. Populasi dalam penelitian ini adalah seluruh siswa kelas XI SMAN 1Ledo tahun pelajaran 20162017. Jumlah populasi 140 siswa yang terbagi dalam lima kelas. Kelas-kelas tersebut adalah XI IPA I, XI IPA 2, XI IPS1, XI IPS 2, XI BABUD. 
Tabel 1 Populasi Penelitian

\begin{tabular}{lll}
\hline Tidak & Kelas & Total \\
\hline 1 & XI IPA 1 & 25 \\
2 & XI IPA 2 & 25 \\
3 & XI IPS 1 & 33 \\
4 & XI IPS 2 & 33 \\
5 & XI BABUD & 24 \\
\hline Total & & 140 \\
\hline
\end{tabular}

Untuk memilih sampel kelompok dan itu harus mewakili semua populasi. Penting bagi peneliti untuk memilih teknik pemilihan sampel. Dalam penelitian ini peneliti menggunakan Cluster Random Sampling untuk memilih data

Cluster sampling adalah teknik pemilihan kelompok tidak secara individual dan semua anggota kelompok terpilih mempunyai karakteristik yang sama. Karena pernyataan tersebut mendorong peneliti untuk memilih sampel melalui cluster random sampling dengan memilih kelas dari populasi secara acak sebagai sampel kelas. Teknik pemilihan sampel adalah peneliti menuliskan nama kelas pada selembar kertas yang terdiri dari 5 kelas yaitu XI IPA I, XI IPA 2, XI IPS1, XI IPS 2, XI BABUD. Kemudian peneliti memasukkannya ke dalam botol kocok kemudian dikocok dan diambil salah satu kertasnya secara acak. Kelas yang dipilih peneliti adalah kelas XI MIPA 2 yang tertulis di makalah untuk mempresentasikan seluruh populasi.
Sebanyak 25 siswa kelas XI MIPA 2 dijadikan sampel dalam penelitian ini.

\subsection{Instrumen Pengumpulan Data}

Unsur penting dalam pengumpulan data adalah pemilihan teknik dan alat pengumpulan data. Karena variabelnya berupa interval atau datanya berupa angka maka peneliti menganalisis datanya dengan cara kuantitatif. Menurut Ross, (2005: 33) "Pengukuran" suatu proses yang memberikan deskriptif numerik untuk beberapa atribut dari suatu objek, orang, atau peristiwa ". Teknik pengukuran digunakan untuk mendapatkan data kuantitatif yang bertujuan untuk mengukur variabel. Dalam penelitian ini peneliti menganalisis data melalui teknik Pengukuran. Dalam penelitian ini peneliti menyediakan dua alat untuk mengumpulkan data yaitu: Tes Kosakata dan Dokumen Tes Performa Berbicara. Sebagaimana dicatat oleh Ary et al (2010: 201) menjelaskan bahwa tes adalah seperangkat rangsangan yang disajikan kepada seorang individu untuk memperoleh tanggapan atas dasar skor numerik yang dapat diberikan. Jadi, peneliti menggunakan tes untuk mengumpulkan nilai pencapaian siswa dalam penguasaan kosakata. Tes penguasaan kosakata dibuat dalam beberapa pilihan. Untuk mengetahui uji validitas dan reliabilitas dalam penelitian ini peneliti menggunakan uji coba Tryout 
test soal dalam uji coba sebanyak 45 soal.

Dari 45 soal uji coba diperoleh 30 soal yang valid dan reliabel sehingga total soal yang diberikan kepada sampel adalah sebanyak 30 soal yang telah divalidisi dan reliabel.

\subsection{Analisis data}

Untuk mengetahui jawaban pertanyaan penelitian maka diperlukan prosedur analisis data. Karena sebagian besar datanya adalah interval dan dalam angka. Maka peneliti menggunakan aplikasi SPSS V.25 untuk membantu peneliti menganalisis data dengan rumus pada SPSS V 25. Paket Statistik untuk Ilmu Sosial (SPSS) adalah program aplikasi perangkat lunak komputer untuk menganalisis data (Creswell, 2012). Peneliti akademis umumnya menggunakan program statistik yang tersedia sebagai program perangkat lunak untuk desktop atau laptop. Jenis rumus yang penulis analisis datanya adalah skor individu, skor mean, standar deviasi, uji korelasi pearson atau wilcoxon, uji distribusi $\mathrm{f}$.

Dalam penelitian ini, peneliti mengumpulkan data dari tes dan penampilan rubrik berbicara. Tes dan kinerja rubrik berbicara digunakan untuk mengetahui tingkat penguasaan kosakata dan keterampilan berbicara siswa, apakah kosakata dan keterampilan berbicara berkorelasi satu sama lain. Analisis data menggunakan uji korelasi Pearson. Uji korelasi pearson digunakan untuk menguji hipotesis korelasi dua sampel jika datanya dalam interval atau rasio. Kemudian hasil korelasi pearson dibandingkan dengan $r-$ tabel untuk mengetahui hipotesis mana yang diterima atau ditolak.

\section{HASIL DAN PEMBAHASAN}

\section{Hasil Penelitian}

\subsection{Hasil Penguasaan Kosakata Siswa}

Dari tabel 3.1 dibawah, peneliti dapat menyimpulkan bahwa rata-rata skor penguasaan kosakata skor individu siswa adalah 69.9992. Artinya, pencapaian penguasaan kosakata siswa dari tabel menunjukkan bahwa siswa berada pada nilai pencapaian penguasaan kosakata sedang. Penulis dapat mengklasifikasikan data ini sebagai media pencapaian.

Diketahui juga dari tabel 3.1 dibawah, untuk nilai minimal yang diperoleh siswa adalah 30,00 dan nilai maksimal yang diperoleh siswa adalah 86,67 . Untuk standar deviasi adalah pukul 14.30. Peneliti dapat menyimpulkan dari data pada tabel 3.1 data menunjukkan bahwa penguasaan kosakata siswa berada pada tingkat prestasi sedang. Artinya siswa memiliki penguasaan kosakata sedang dalam bahasa Inggris. 
Tabel 3.1

\begin{tabular}{|c|c|c|c|c|c|c|}
\hline & $\mathrm{N}$ & $\begin{array}{l}\text { Minim } \\
\text { um }\end{array}$ & $\begin{array}{c}\text { Maksim } \\
\text { um }\end{array}$ & $\begin{array}{r}\text { Juml } \\
\text { ah }\end{array}$ & $\begin{array}{c}\text { Berar } \\
\text { ti }\end{array}$ & $\begin{array}{c}\text { Std. } \\
\text { Deviasi }\end{array}$ \\
\hline KOSA & \multirow{2}{*}{25} & \multirow{2}{*}{30.00} & \multirow{2}{*}{86.67} & 1749 & 69,99 & \multirow{2}{*}{14.30475} \\
\hline KATA & & & & 98 & 92 & \\
\hline Valid & & & & & & \\
\hline $\begin{array}{c}\mathrm{N} \\
\text { (listwi }\end{array}$ & 25 & & & & & \\
\hline se) & & & & & & \\
\hline
\end{tabular}

Penulis dapat menyimpulkan bahwa nilai rata-rata dari pencapaian penguasaan kosakata siswa adalah 69,99. nilai maksimal yang diperoleh siswa adalah 86,67. nilai minimum yang diperoleh siswa adalah 30.00 dan standar deviasi 14.30. Penulis menyimpulkan bahwa siswa memiliki pencapaian penguasaan kosakata pemahaman sedang.

\subsection{Hasil Keterampilan Berbicara Siswa}

Hasil pencapaian keterampilan berbicara siswa disajikan pada tabel 3.2. Berikut ini di bawah tabel hasil prestasi keterampilan berbicara siswa.

Tabel 3.2

\begin{tabular}{|c|c|c|c|c|c|}
\hline & $\begin{array}{r}\text { Mini } \\
\mathrm{N} \text { mum }\end{array}$ & $\begin{array}{r}\text { Maksi } \\
\text { mum }\end{array}$ & $\begin{array}{r}\text { Juml } \\
\text { ah }\end{array}$ & $\begin{array}{r}\text { Berar } \\
\text { ti }\end{array}$ & $\begin{array}{r}\text { Std. } \\
\text { Deviasi }\end{array}$ \\
\hline BERBI & \multirow{2}{*}{2550.00} & \multicolumn{3}{|c|}{$1775,71.00$} & \\
\hline CARA & & 00 & 00 & 00 & $9.5 / 421$ \\
\hline $\begin{array}{l}\text { Valid N } \\
\text { (listwise) }\end{array}$ & 25 & & & & \\
\hline
\end{tabular}

Dari tabel 3.2, peneliti dapat menyimpulkan bahwa rata-rata skor keterampilan berbicara individu siswa adalah 71. Artinya, pencapaian keterampilan berbicara siswa dari tabel telah menunjukkan bahwa siswa berada pada skor ketuntasan keterampilan berbicara tingkat sedang. Penulis dapat mengklasifikasikan data ini sebagai media pencapaian.

Dari tabel 3.2, untuk nilai minimal yang diperoleh siswa adalah 50 dan nilai maksimal yang diperoleh siswa adalah 85 Untuk standar deviasi adalah 9,57. Peneliti dapat menyimpulkan dari data pada tabel 4 bahwa data menunjukkan bahwa kemampuan berbicara siswa berada pada tingkat pencapaian sedang. Artinya siswa memiliki kemampuan berbicara sedang dalam mata pelajaran bahasa Inggris.

Penulis dapat menyimpulkan bahwa rata-rata skor pencapaian keterampilan berbicara siswa adalah 71 nilai maksimal yang diperoleh siswa adalah 85 nilai minimum yang diperoleh siswa adalah 50 dan standar deviasi 9,57. Penulis menyimpulkan bahwa siswa memiliki tingkat pemahaman sedang terhadap pencapaian keterampilan berbicara siswa.

\subsection{Hasil Pengujian Validitas dan Reliabilitas Instrumen}

Dalam penelitian ini, peneliti menggunakan kinerja tes berbicara untuk mendapatkan nilai prestasi berbicara siswa kelas sebelas tahun ajaran 2016-2017. Peneliti bekerjasama dengan guru bahasa Inggris untuk mendapatkan data hasil skor 
keterampilan berbicara. Guru meminta kepada siswa untuk mendeskripsikan tentang guru bahasa Inggrisnya berdasarkan materi umum pertama ciri khusus guru bahasa Inggris, kedua penampilannya di sekolah, dan ketiga cara mengajarnya. Jadi, guru memfokuskan untuk menilai 4 aspek kinerja berbicara siswa yang pertama kefasihan, tata bahasa, pemahaman dan kosakata masing-masing aspek mendapat skor mulai dari 1 sampai 5 poin sehingga total semua skor adalah 20 poin. Lihat Penilaian Rubrik Berbicara Diadaptasi dari Brown (2004: 172-173) dalam penelitian ini peneliti meminta kepada guru bahasa Inggris untuk mendapatkan hasil prestasi berbicara. Uji validitas adalah cara untuk memastikan apakah data yang digunakan untuk mengukur variabel valid atau tidak. Seperti dicatat oleh (Lodico et al. 2010, p.93) validitas berfokus untuk memastikan bahwa apa yang diklaim oleh instrumen untuk diukur adalah benar-benar apa yang sedang diukur. Pernyataan ini dipertajam oleh (Cohen et al. 2007, p.134), "validitas adalah kunci penting untuk penelitian yang efektif. Jika sebuah penelitian tidak valid maka tidak ada gunanya. Validitas dengan demikian merupakan persyaratan untuk penelitian kualitatif dan kuantitatif atau naturalistik". Uji validitas merupakan cara untuk memastikan apakah data yang digunakan untuk mengukur variabel valid atau tidak. Sebagaimana dicatat oleh
Lodicoet al (2010: 93) validitas berfokus pada memastikan bahwa apa yang "diklaim" oleh instrumen untuk diukur adalah benar-benar apa yang sedang diukur. Pernyataan ini dipertajam oleh Cohen et al (2007: 134), "validitas adalah kunci penting untuk penelitian yang efektif. Jika sebuah penelitian tidak valid maka tidak ada gunanya. Validitas dengan demikian merupakan persyaratan untuk penelitian kuantitatif dan kuantitatif atau naturalistik".

Karena pernyataan diatas peneliti meyakini bahwa validitas merupakan kunci penting yang penting untuk memeriksa keefektifan tes kosa kata tersebut valid atau tidak. Untuk menguji validitas tes kosakata peneliti mengadakan tes try out yang dilakukan terhadap 10 siswa kelas XI IPS 2 dengan total $(\mathrm{n}=10)$ melakukan tes try out. Terdapat 45 pertanyaan dengan empat alternatif jawaban a, b, c, dan d. Data yang diperoleh diolah dengan SPSS V 16.0 dianalisis dengan koefisien korelasi momen produk Pearson (Pearson r) sebagaimana dinyatakan oleh Cohen, Manion, dan Morrison, (2007: 528) bahwa banyak penelitian pendidikan yang berkaitan dengan membangun hubungan timbal balik antar variabel dan dua korelasi yang paling umum digunakan adalah korelasi urutan peringkat spearman untuk data ordinal dan korelasi momen produk Pearson untuk data interval dan 
rasio. Peneliti akan menggunakan SPSS V 16.0 untuk membantu peneliti menghitung data. Dalam menganalisis masing-masing item tes (r Hitung) diperoleh skor $r$ tabel dengan signifikansi $5 \%$ pada $(\mathrm{n}=10)$. Skor $\mathrm{r}$ tabel pada signifikansi $5 \%$ pada $\mathrm{n}=$ 10 adalah 0,632 . Soal yang memiliki $r$ hitung lebih rendah dari 0,632 dieliminasi karena bukan soal tes yang valid. Dari hasil uji validitas didapatkan 30 soal valid dan 15 valid. Soal-soal yang diujicobakan diberikan kepada sampel di kelas. Pertanyaan yang valid dalam penelitian ini adalah: 1, 2, 3, 4, 7, 9, 11, 15, 18, 19, 20, $22,23,24,25,26,27,28,29,30,33,34$. $35,38,39$, dan 40 .

Untuk memeriksa apakah data instrumen dapat diandalkan atau tidak, penting untuk mengetahui reliabilitas instrumen tersebut. Dalam penelitian ini peneliti menggunakan tes uji coba untuk menghitung uji reliabilitas kosakata siswa. Pentingnya reliabilitas diperlukan untuk mengukur apakah data instrumen reliabel. Creswell (2012: 159) menyatakan bahwa reliabilitas secara umum lebih mudah dipahami karena merupakan ukuran konsistensi. Artinya nilai dari tes tersebut harus stabil dan konsisten meskipun tes tersebut digunakan pada kesempatan yang berbeda atau bila digunakan oleh orang lain akan memberikan hasil yang sama. Untuk mengetahui homogenitas data maka peneliti menganalisis data dengan rumus alpha cronbach. Ini didukung oleh Ary et al (2010: 247), "peneliti menggunakan Cronbach alpha ketika ukuran memiliki item yang tidak dinilai hanya sebagai benar atau salah, seperti skala sikap atau tes esai tetapi skor item dapat mengambil berbagai nilai. Dalam penelitian ini peneliti mengolah uji reliabilitas dengan menggunakan rumus alpha cronbach pada SPSS V.16.0 untuk instrumen (soal tes) yang digunakan untuk menentukan reliabilitas soal tes. Dalam menganalisis uji reliabilitas, peneliti membandingkan skor Cronbach alpha yang diolah dengan menggunakan SPSS V 16.0 dengan skor $r$ tabel dengan signifikansi $5 \%$ pada $\mathrm{n}=10$. Skor $r$ tabel signifikansi $5 \%$ pada $\mathrm{n}=10$ adalah 0,632. tes soal reliabel jika skor Cronbach alpha lebih dari 0,632. Hasil reliabilitas dengan menggunakan SPSS 16 ditunjukkan di bawah ini:

Tabel 3.3

$\begin{array}{cc}\text { Cronbach's Alpha } & \text { N dari Item } \\ 0,968 & 45\end{array}$

Dari table 3.3 uji reliabilitas di atas menunjukkan nilai Cronbach alpha sebesar 0,968 untuk 45 butir soal. Lebih dari nilai r tabel nilai Cronbach alpha lebih dari 0,632. dapat disimpulkan bahwa soal tes dianggap reliabel.

Untuk menguji tes keterbacaan peneliti menguji keterbacaan pada siswa kelas XI 
(BABUD) di SMAN 1 Ledo peneliti memberikan 5 soal dengan pilihan ya dan tidak menjawab mengacu pada tes kinerja berbicara dengan $\mathrm{n}=25$ siswa dan didapatkan hasil $100 \%$ Siswa XI Babud Mereka Dijawab Ya, artinya sudah paham dengan tes kinerja berbicara.

\subsection{Hasil Pengujian Normalitas}

Untuk mengukur signifikansi rata-rata posttest kedua kelompok, digunakan uji t. Di sini peneliti melakukan independent sample t-test karena digunakan untuk menguji apakah ada perbedaan antara kedua kelompok (Ary, et al., 2010, p.171). Hasil penelitian digunakan sebagai upaya untuk memverifikasi hipotesis. Data dianalisis dengan menggunakan SPSS 25. Peneliti melakukan uji normalitas untuk prestasi kosakata siswa dan prestasi berbicara untuk menentukan rumus untuk mengetahui korelasi diantara keduanya. Peneliti menggunakan KolmogorovSmirnov untuk menguji data. Perhitungan tes dilakukan dengan SPSS V 25.

Dari Hasil uji normalitas penguasaan kosakata, data dihitung dengan SPSS V.25. Penghitungan data nilai normalitas sebesar 0,90 Tabel tersebut menunjukkan bahwa hasil uji normalitas untuk prestasi kosakata siswa $\mathrm{n}=25$ dan $\alpha=0,05$ adalah 0,238 sehingga 0,900 lebih besar dari 0,238 yang berarti Ho ditolak dan data hasil belajar kosakata siswa berdistribusi normal.
Sedangkan untuk hasil dari uji normalitas keterampilan berbicara, data dihitung dengan SPSS V.25. Penghitungan data nilai normalitas sebesar 0,90 , tabel tersebut menunjukkan bahwa hasil uji normalitas untuk prestasi belajar berbicara siswa sebesar 0,692. Dimana nilai D Kritis untuk $\mathrm{n}=25$ dan $\alpha=0,05$ adalah 0,238 sehingga 0,692 lebih besar dari 0,238 yang berarti Ho ditolak dan data hasil belajar keterampilan berbicara siswa berdistribusi normal.

\subsection{Hasil Korelasi antara Penguasaan Kosakata dan Keterampilan Berbicara}

Tabel 3.4

\begin{tabular}{llll}
\hline & & $\begin{array}{l}\text { KOSA } \\
\text { KATA }\end{array}$ & $\begin{array}{l}\text { BERBICA } \\
\text { RA }\end{array}$ \\
\hline KOSA & Korelasi & 1 & $0,943 * *$ \\
KATA & Pearson & & \\
& Sig. (2- & & .000 \\
& tailed) & & \\
& N & 25 & 25 \\
BERBICAR & Korelasi & & \\
A & Pearson & $0,943 * *$ & 1 \\
& Sig. (2- & & \\
& tailed) & & \\
& N & 25 & 25 \\
\hline
\end{tabular}

**. Korelasi signifikan pada level 0,01 (2-tailed).

Berdasarkan tabel 3.4 Korelasi antara penguasaan kosakata dan keterampilan berbicara. Peneliti dapat menyimpulkan bahwa nilai korelasi 
Pearson sebesar 0,943. Berdasarkan hasil perhitungan diperoleh nilai koefisien korelasi antara penguasaan kosakata dengan keterampilan berbicara sebesar 0,943 dan berdasarkan tingkat signifikansi $\mathrm{r}$ tabel dengan $\mathrm{n}=25$ sebesar 0,396 sehingga nilai $r$ hitung sebesar 0,943 lebih tinggi dari $r$ tabel 0,396 yang berarti hipotesis nol (Ho) ditolak, dengan demikian ada korelasi antara penguasaan kosakata dengan prestasi berbicara mereka.

Kemampuan kelas sebelas SMAN 1 Ledo tahun ajaran 2016-2017. Korelasi antara penguasaan kosakata dan keterampilan berbicara dihitung dengan menggunakan rumus Korelasi Pearson Product Moment dan koefisien korelasi 0,943. Menurut Cohen et al (2007: 536) 0,943 dikategorikan sebagai Korelasi Dekat. Artinya penguasaan kosakata siswa berkorelasi kuat dengan keterampilan berbicara siswa dengan kata lain prestasi kosakata siswa tertinggi maka prestasi berbicara siswa juga tinggi.

\section{Pembahasan}

Tingkat penguasaan kosakata dan keterampilan berbicara siswa kelas XI SMAN 1 Ledo sebagai penghitungan skor rata-rata variabel prestasi kosakata dan prestasi berbicara dianalisis melalui rumus skor rata-rata dan data menunjukkan bahwa siswa kelas sebelas SMAN 1 Ledo masuk dalam kategori baik.
Hubungan penguasaan kosakata dengan keterampilan berbicara siswa kelas XI SMAN 1 Ledo dalam penelitian ini peneliti menghitung normalitas data melalui rumus Kolmogorov-Smirnov menunjukkan bahwa data berdistribusi normal artinya analisis pengujian hipotesis menggunakan parametrik. Berdasarkan statistik, maka peneliti menggunakan rumus korelasi Pearson Product Moment untuk menganalisis data dan hasil penelitian menunjukkan bahwa ada hubungan antara penguasaan kosakata dengan keterampilan berbicara pada siswa kelas XI SMAN 1 Ledo tahun pelajaran 2016-2017.

Besarnya hubungan yang signifikan antara penguasaan kosakata dengan keterampilan berbicara siswa kelas XI SMAN 1 Ledo maka peneliti menghitung ulang menggunakan nilai $r$ hitung yang menunjukkan bahwa data berkorelasi positif dan tingkat signifikan tersebut dikategorikan sebagai korelasi erat.

Berdasarkan temuan di atas peneliti juga melampirkan hasil studi tentang hubungan penguasaan kosakata dengan keterampilan berbicara dari para ahli. Pertama dari Nation in Alqahtani (2015: 22), menjelaskan bahwa "hubungan antara pengetahuan kosakata dan penggunaan bahasa sebagai pelengkap: pengetahuan kosakata memungkinkan penggunaan bahasa dan, sebaliknya, penggunaan bahasa menyebabkan peningkatan 
pengetahuan kosakata”. Artinya kosakata dan bahasa itu sendiri memiliki keterkaitan yang kuat. Orang bisa menggunakan bahasa lisan jika memiliki kosakata yang baik dan sebaliknya. Dengan bertambahnya kosakata maka bahasa lisan atau lisan juga semakin meningkat dan sebaliknya semakin bertambahnya kosakata juga semakin meningkat.

Pernyataan ini juga diperkuat oleh Nation and Waring dalam Mehring (2005: 3), "Pengetahuan kosakata memungkinkan penggunaan bahasa, penggunaan bahasa memungkinkan peningkatan pengetahuan kosakata, pengetahuan dunia memungkinkan peningkatan pengetahuan kosakata dan penggunaan bahasa dan sebagainya”. Artinya penggunaan kosakata dan bahasa saling melengkapi karena besarnya pengetahuan kosakata yang dimiliki masyarakat memungkinkan mereka untuk menggunakan bahasa lisan dengan baik. Dapat disimpulkan bahwa dengan meningkatnya pengetahuan kosakata maka keterampilan berbicara juga meningkat.

\section{KESIMPULAN}

Berdasarkan analisis data yang diperoleh dari pembahasan pada hasil penelitian, peneliti menentukan kesimpulan tentang penelitian ini. Peneliti menyimpulkan tingkat pencapaian kosakata dan prestasi berbicara siswa kelas XI SMAN 1 Ledo tahun ajaran 2016-2017 diperoleh dengan cara menghitung rumus skor rata-rata dan didapat hasil tingkat prestasi kosakata dan kemampuan berbicara siswa. Prestasi berada pada level yang baik.

Korelasi penguasaan kosakata dengan keterampilan berbicara siswa kelas XI SMAN 1 Ledo dihitung dengan rumus Korelasi Pearson-Product Moment dan hasilnya nilai $r$ hitung lebih tinggi dari $r$ tabel artinya Ha diterima yang artinya ada korelasi antar kosakata. penguasaan dan keterampilan berbicara pada kelas sebelas di SMAN 1 Ledo tahun ajaran 2016-2017.

Peneliti juga menyimpulkan bahwa tingkat korelasi yang signifikan antara penguasaan kosakata dengan keterampilan berbicara di kelas XI SMAN 1 Ledo termasuk dalam kategori korelasi positif dekat (Diambil dari Cohen et al 2007: 536) yang berarti penguasaan kosakata dan keterampilan berbicara memiliki korelasi yang kuat. dan ketika pencapaian kosakata meningkat, prestasi berbicara juga meningkat.

\section{DAFTAR PUSTAKA}

Alqahtani, Mofareh. (2015). Pentingnya Kosakata dalam Pembelajaran Bahasa dan Cara Diajarkan. Jurnal Internasional Pengajaran dan Pendidikan.

Anova, Candra. D K. (2013). Hubungan Penguasaan Kosakata Mahasiswa dan Keterampilan Berbicara pada 
Semester V Program Studi Bahasa

Inggris Universitas Pasir

Pengaraian. Yogyakarta: Tidak diterbitkan

Ary, Donald dkk. (2010). Pengantar Penelitian dalam Pendidikan. Amerika Serikat: Wardsworth.

Barras, Robert. (2006). Berbicara untuk Diri Anda Sendiri Sebuah Panduan untuk Siswa. New York: Routledge. Baker, Joanna., Westrup, Heather. (2003) Keterampilan Berbicara Penting. Kontinum: VSO Inc.

Bernstein, Stephen., Bernstein, Ruth. (1999). Teori dan Permasalahan Unsur Statistik. New york: The McGraw-Hili Companies, Inc.

Brown, H. Douglas. (2004). Prinsip Penilaian Bahasa dan Praktik Kelas. New York: Pearson Education Inc.

Cohen, L., Manion, L., Morrison, K. (2007). Metode Penelitian dalam Pendidikan. New York: Routledge Creswell, John W. (2012). Penelitian Pendidikan Boston: Pearson Education Inc.

Creswell, John W. (2009). Desain Riset

Edisi Ketiga. Los Angeles: Sage Publication Inc.

Floris, Debora F. (2013). Sukses Di Akademik Bahasa Inggris.Jakarta. Grahallmu.

Lodico, Marguerite G. Spaulding, Dean T., Voegtle, Katherine H. (2010) Metode dalam Penelitian
Pendidikan Edisi 2. San Francisco: John Wiley \& putra.

Loraine, Susie. (2008). Vocabulary Developing.Boston.MA: Super Duper Publication.

Mehring, Jeff G. 2005). Mengembangkan Kosakata dalam Akuisisi Bahasa Kedua. Singapura: Jurnal RELC.

Ross, NK. (2005). Riset Pendidikan: Beberapa Konsep dan Terminologi Dasar. Paris, Prancis: UNESCO.

Sari, JiatiEndah., B, Nunung., Hastini. (2013) Korelasi Antara Penguasaan Kosakata Siswa dan Keterampilan Mendengarkan Palu: E-Journal Teaching Society.

Urdan, Timothy C. (2005). Statistik dalam Bahasa Inggris Biasa Edisi ke-2. Mahwah: Lawrence Erlbaum Associates, Inc.

Yuwinda. (1998). huungan penguasaan kosakata dengan kemampuan berbicara pada siswa kelas XI Man Model Palangkaraya. Palangka Raya: Tidak dipublikasikan. 